\title{
Compatibility of Eco-Friendly, Sustainable Living with Urbanization: A Case-study of The Art of Living International Center near Bengaluru
}

\author{
Divya Kanchibhotla ${ }^{1}$, Nupur Rao ${ }^{1} \&$ Prateek Harsora ${ }^{1}$ \\ ${ }^{1}$ Sri Sri Institute for Advanced Research, The Art of Living International Center, Bengaluru, India \\ Correspondence: Divya Kanchibhotla, Sri Sri Institute for Advanced Research, The Art of Living International \\ Center, 21st km Kanakapura Road, Bengaluru-560082, Karnataka, India. Tel: 91-829-689-7160. Email: \\ director.ssiar@artofliving.org
}

Received: June 26, 2020

Accepted: August 17, 2020

Online Published: September 29, 2020

doi:10.5539/jsd.v13n5p92

URL: https://doi.org/10.5539/jsd.v13n5p92

\begin{abstract}
In the past few decades, urban growth in most parts of the world has disregarded sustainable practices, contributing to a myriad of global problems. With $68 \%$ of the global population projected to reside in urban areas by 2050 , it is essential that we espouse and implement effective sustainable solutions immediately. This study focuses upon the smart sustainable practices adopted at the international headquarters of The Art of Living near Bengaluru, the 'Silicon Valley of India'. Situated in a rapidly urbanizing area barely $20 \mathrm{kms}$ from the busy metropolis, and characterized by a large floating population that varies from 3,000-6000 visitors per week, apart from almost 2000 residents, this bustling community has lush green cover, extremely rich biodiversity and excellent air quality. Some of the sustainable practices adopted here include permaculture, efficient waste management, moving towards the use of clean energy, etc. This paper posits that this unique community exemplifies the possibility of creating an 'oasis of sustainability' in the arid desert of urbanization.
\end{abstract}

Keywords: urbanization, sustainable practices, waste management, permaculture, clean energy, people's participation

\section{Introduction}

Urbanization is an inevitable yet important aspect of development. In the past few decades, urban growth in many parts of the world has focused on economic development and seldom incorporated sustainable ecological aspects. This has contributed to a myriad of global problems including skewed urban population growth, unplanned urban sprawls and rapid depletion of non-renewable natural resources. A good part of the damage to the environment is irreversible and exceeds its self-purification and regeneration capacity. A UN Habitat think piece on "Sustainable Urbanization" (2012) recognizes that urbanization is "a major factor in environmental trends and sustainability processes," and provides not just the setting and the underlying base, but also the momentum for global change. With urban population projected to increase to $68 \%$ by 2050 (United Nations Department of Economic and Social Affairs [UNDESA], 2019), it is crucial that urbanization also be sustainable.

Sustainable urbanization is that which caters to the needs of the present generation without compromising the needs of the future generations. It reduces the demand on resources and minimizes the impact on the natural environment, while ensuring a healthy, prosperous human situation. Much research exists about initiatives that need to be employed. However, sustainability depends on whether and how initiatives are actually implemented, and this is decisive in how well urban growth is managed. Bibri and Krogstie (2017) point out that innovative solutions need to be developed and applied in this area. The integration of multiple sustainable practices at the same time is essential, especially in nations where the phenomenon of urbanization is taking place at a rapid pace. This study draws attention to some of the smart sustainable practices adopted and integrated with one another at The Art of Living International Center (henceforth the Center), an urban community located in the vicinity of one of the biggest metropolises in India, Bengaluru. While sustainability is characterized by environmental, social and economic concerns, in the context of this research, the environmental aspect is emphasized, including safeguarding the natural environment (flora and fauna), conserving natural resources and utilizing clean energy, which is itself premised upon local people's participation in these initiatives. 
Bengaluru is an IT hub, popularly known as the 'Silicon Valley of India,' and has a population of 12.34 million (www.worldpopulationreview.com, 2017). Approximately $57 \%$ of the city's land area is built up, with over 250 acres taken up by gardens (Note 1). While Bengaluru is one of the less polluted cities of India, with its air quality measuring an average of $32.6 \mathrm{ug} / \mathrm{m} 3$ in 2019 (IQAir, 2020), this is still far higher than WHO standards (10ug/m3). The Art of Living International Center, more commonly known as Bangalore Ashram, is the headquarters of The Art of Living, an NGO which operates in over 156 countries. It is located on the Old Mysore-Kanakapura Road, $21 \mathrm{~km}$ south-west of the city of Bengaluru in Karnataka, southern India. The Center is home to a resident population of about 1400 people, with an estimated 500-800 temporary residents (people attending various programs offered by the Center) on any given day. Run by volunteers, the Center offers various residential and non-residential programs, ranging from 3-45 days, throughout the year. It is thus characterized by high foot traffic as well, with a large floating population of approximately 3,000-6000 visitors per week. The kitchen at the Center feeds an average of over 8,000 people at mealtimes each day. Despite this kind of traffic, the Center has lush green cover, meets a large part of its vegetable and fruit needs, is extremely rich in biodiversity and has much better air quality than the city.

The Center has over 80 departments that manage and run the affairs of the NGO. The uniqueness of this community is that the people here are highly aware of the benefits of adopting a sustainable and eco-friendly lifestyle, and give importance to the protection of the environment. They participate and collaborate in ensuring sustainability by consciously adopting sustainable lifestyles, choosing to reduce, reuse and recycle, and at the same time adopt sustainable practices at the community level, thereby considerably reducing their ecological footprint. This is the key difference between the city and this urban community: the latter has integrated many sustainable practices into their lives, including practices such as natural farming and permaculture, an efficient system of waste management that includes re-use of recycled water to water plants, use of waste paper and cotton for making handmade paper, production of compost from uncooked vegetable and plant waste, conversion of waste plastic into fuel, and even conversion of cooked food waste to biogas. Further, the community also attempts to reduce its load on other nonrenewable resources by using solar energy to run electrical appliances, treating and reusing wastewater and harvesting rainwater to recharge ground water.

This suggests that sustainable urbanization becomes possible when people participate in building communities that are sensitive in terms of their connectivity with nature, and when their behavior and practices are guided by environmental concerns: urbanization can be compatible with eco-friendly, sustainable practices, and 'people's participation' is a key factor in instituting sustainable urbanization. Viewing the Center as an 'oasis of sustainability' in the arid desert of urbanization, this paper posits that it offers an environmentally sustainable model worth emulating: through practices similar to those followed at the Center, which are scalable and replicable, sustainable urbanization is not just conceivable but actionable.

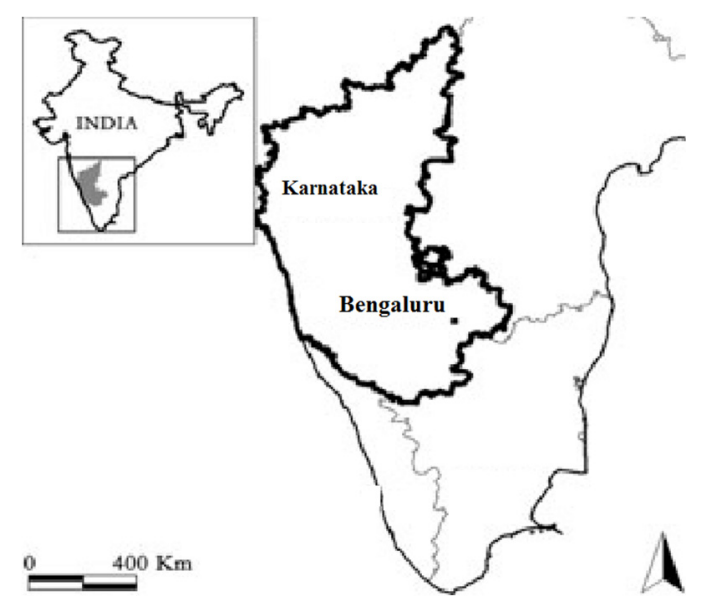

Figure 1. Geographic location of Bengaluru

Source: www.worldmapwithcountries.net 


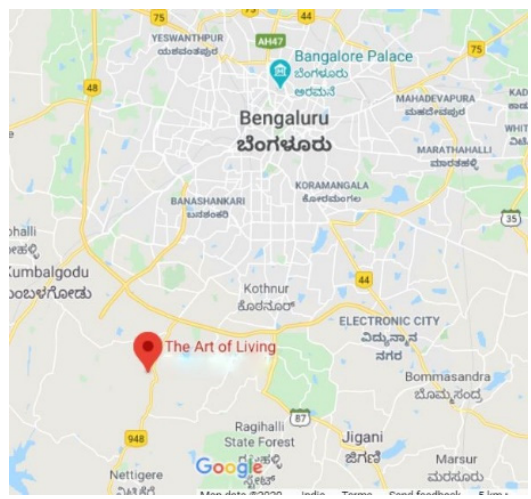

Figure 2. Location of The Art of Living International Center in relation to the city of Bengaluru Source: Google Maps

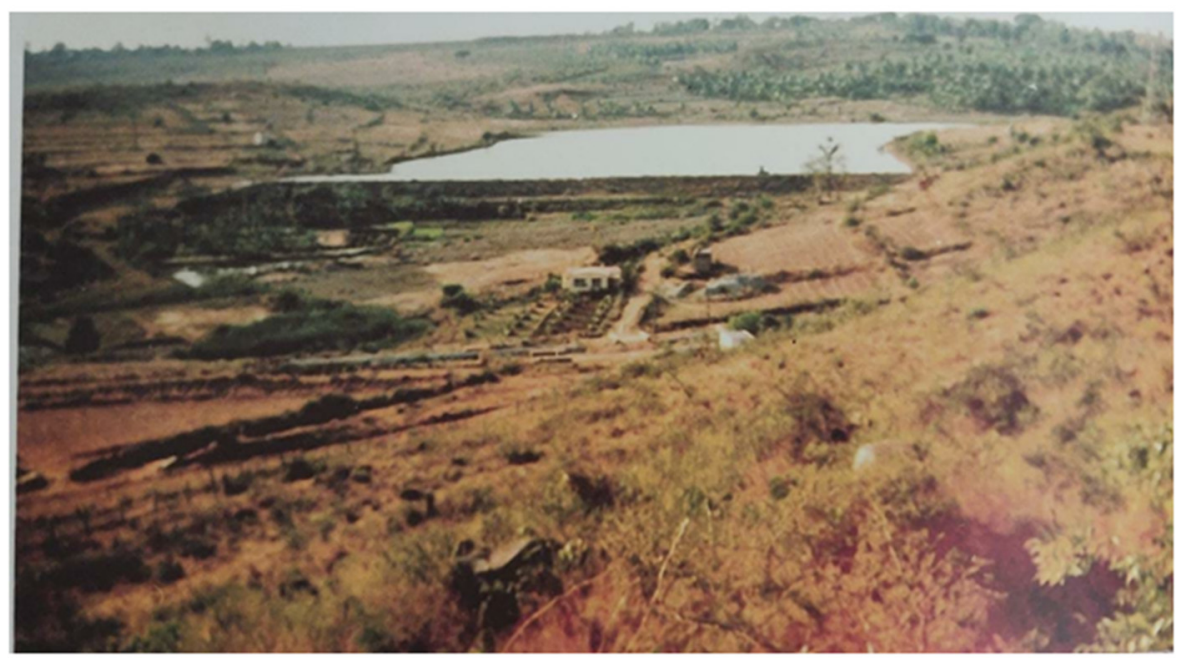

Figure 3. The area a little over 30 years ago

Source: Archives of The Art of Living International Center

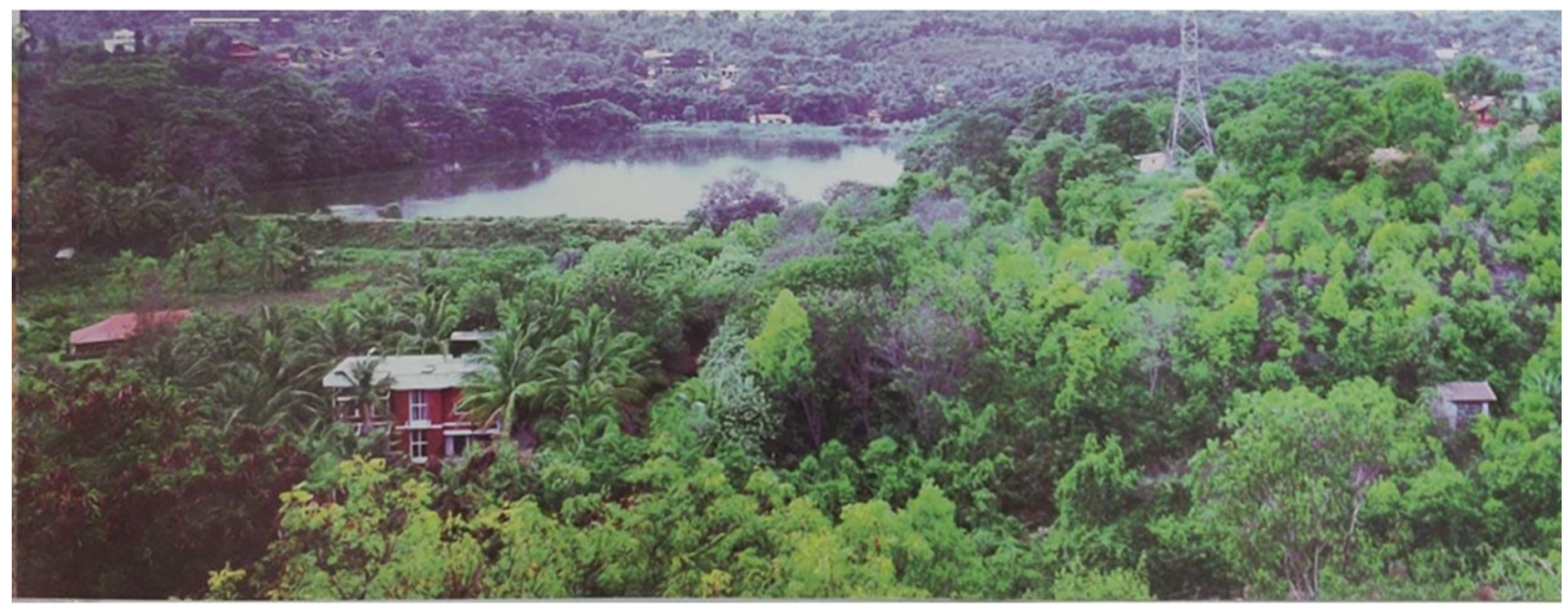

Figure 4. The area in the present

Source: Archives of The Art of Living International Center 


\section{Method}

Sustainable urbanization is a complex process given that multiple concerns need to be addressed. At the Center, diverse techniques are being tried out towards its achievement. This paper focuses on a few of these sustainable practices, mainly the use of natural farming, permaculture and waste management, while also drawing attention to the use of clean energy. The data presented in this study is drawn from the Center's administration and specific departments, as well as semi-structured interviews with several members of the management and staff across various departments between September 2018 and September 2019, and supplemented by site visits and field observations of various eco-friendly processes and procedures followed at the Center over the months of JulySeptember 2019.

\section{Some Sustainable Practices at the Center}

\subsection{Natural Farming and Permaculture in Cultivation}

Bambrey (2014 [2006]) made a hard-hitting statement when he said that "If agriculture fails, civilization falls! That is why a permanent/sustainable agriculture is of paramount importance." At the Center, an attempt has been made to attend to the environment while taking care of the needs of people by implementing such permanent/sustainable agriculture through natural farming and permaculture.

\subsubsection{Natural/Organic Farming}

Natural farming using traditional chemical-free cow-based agricultural practices was initiated in 2003, with a gaushala or cow shelter housing indigenous Indian cows alongside. A part of the land at the Center is given over to cultivation using traditional methods of natural, cow-based chemical-free farming practiced by the Indians in ancient times, termed "Rishi-Krishi" (pure farming) - respecting nature and carried out well in accordance with it. This is evidenced as soon as one enters the Center, where along a narrow pathway leading away from the main reception are groves of coconut palms with the earth fertilized with cow dung. A little further ahead, fresh vegetable produce is ready for harvest. Other fruit trees like sapota (sapodilla) and pomegranate also line some of the walkways.

Apart from this, some 400 acres of land are also farmed according to this method, integrating natural farming and organic farming technologies. Along with natural fertilizers and pesticides developed from cow dung and cow urine mixed with leaves of trees like neem, compost made from food waste is also used here. Vegetables such as cabbage, bottle gourd, ridge gourd, lady's finger, beans, cauliflower, capsicum, tomato, green chillies, zucchini, and pumpkin are cultivated in large quantities, along with smaller quantities of bitter gourd, snake gourd, ash gourd, cucumber, radish, and greens, such as broccoli, amaranth, spinach, and fenugreek. Some fruits such as musk melon and water melon are also produced, as also Brazil nut and a variety of fruit from the custard apple family.

\subsubsection{Permaculture (Permanent Agriculture)}

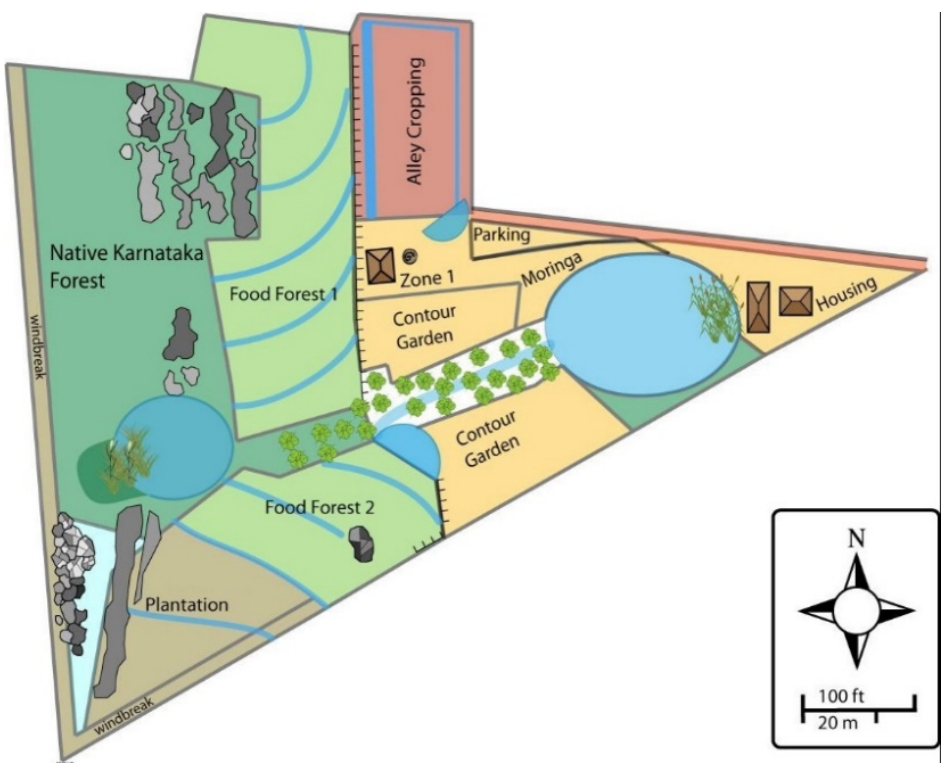

Figure 5. Permaculture farm designed by Brecht Deriemaeker and Nick Tittle

Source: The Art of Living International Center 
A seven-acre piece of rocky land has been developed as a full-fledged permaculture farm. Initiated in 2013 with the help of consultants from The Panya Project, the site was designed using the three ethics and 12 design principles of permaculture. It fits Holmgren's definition of permaculture as "consciously designed landscapes which mimic the patterns and relationships found in nature, while yielding an abundance of food, fiber and energy for provision of local needs" (Holmgren 2002).

The site, which was described by the consultants as being "in a severely degraded state due to overgrazing, erosion and leaching of the soils," (Note 2) is now one where many varieties of flowers, fruits, and vegetables including green leafy vegetables grow, as listed in Table 1 below.

Table 1. Varieties of flowers, fruits, vegetables and green leaves grown at the Art of Living Permaculture farm

\begin{tabular}{lll}
\hline Category & Botanical name & Common name \\
\hline Flowers & Tagetus patula & Marigold \\
\hline
\end{tabular}

Small quantities of other flowering plants such as roses, brahma kamal (night blooming Cereus), cannonball, jasmine, night queen, sunflower, hibiscus

\begin{tabular}{|c|c|c|}
\hline Fruits & Musa spp. & Banana \\
\hline & Mangifera indica & Mango \\
\hline & Punica granatum & Pomegranate \\
\hline & Carica papaya & Papaya \\
\hline & Passiflora edulis & Passion fruit \\
\hline \multirow[t]{11}{*}{ Vegetables } & Raphanus raphanistrum subsp. sativus & Radish \\
\hline & Momordica carantia & Bitter gourd \\
\hline & Luffa acutangular & Ridge gourd \\
\hline & Lagenaria siceraria & Bottle gourd \\
\hline & Cucurbita moschata & Sweet pumpkin \\
\hline & Benincasa hispida & White pumpkin \\
\hline & Emblica officinalis & Indian goose berry \\
\hline & Phaseolus vulgaris & French beans \\
\hline & Abelmoschus esculentus & Okra \\
\hline & Solanum lycopersicum & Tomato \\
\hline & Solanum lycopersicum var. cerasiforme & Cherry Tomato \\
\hline
\end{tabular}




\begin{tabular}{|c|c|c|}
\hline & Murraya koenigii & Curry leaf \\
\hline & Coriandrum sativum & Coriander \\
\hline & Mentha spicata & Mint \\
\hline & Saccharum officinarum & Sugarcane \\
\hline & Zea mays & Maize \\
\hline & Averrhoa carambola & Star Fruit \\
\hline & Ipomoea batatas & Sweet potato \\
\hline & Zingiber officinale & Ginger \\
\hline & Curcuma longa & Turmeric \\
\hline & Capsicum аппиит & Green chillies \\
\hline & Citrus limon & Lemon \\
\hline \multirow[t]{5}{*}{ Green leafy vegetables } & Amaranthus retroflexus & Common amaranth \\
\hline & Spinacia oleracea & Spinach \\
\hline & Trigonella foenum-graceum & Fenugreek \\
\hline & Lactuca sativa & Lettuce \\
\hline & Eruca vesicaria sp. Sativa & Rocket leaf \\
\hline \multirow[t]{2}{*}{ Medicinal } & Aloe vera & Aloe \\
\hline & Trachyspermum ammi & Carom \\
\hline
\end{tabular}

Apart from these, moringa trees form a windbreaker and many plants of medicinal value grow wild.

\subsubsection{Biodiversity}

Apart from the floral and faunal diversity that has been documented above, the Center now looks like a forested area comprising many other species of flora as well as fauna. It has become the home to several native plant species along with a host of birds, butterflies, reptiles and small mammals, as shown in Figure 6. Among the varieties of birds are 22 rare bird species as well. 


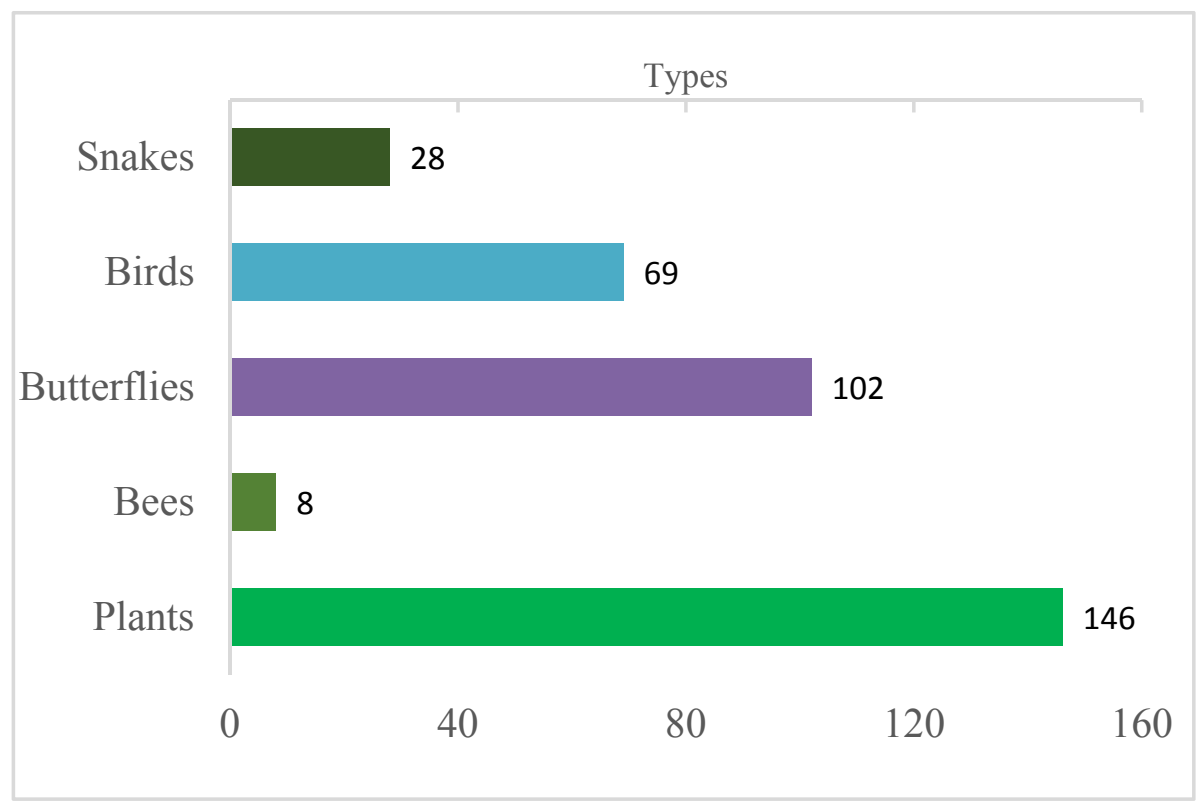

Figure 6. Biodiversity at the art of living international center

This form of agriculture also lays emphasis on the importance of recharging groundwater, and this has become the guiding principle in the management of and plans for the farm. The growth of vegetation along with water harvesting has also impacted ground water levels, which have risen considerably. The swales collect rainwater and allow it to percolate into the earth. Overflows run into two natural ponds, and two smaller artificially created ponds.

Rainwater run-off is also efficiently harvested in other parts of the campus through the 'tap-it-where-it-falls' method, and natural lows are used as collection pools for infiltration.

\subsection{Waste Management}

The Center has excellent waste management practices in place. To segregate waste at the source, separate bins have been put up for dry and wet waste on the entire campus. Waste is collected on a daily basis. Garbage from nearby villages is also collected and brought to the Waste Management Plant, where all the waste is manually segregated. Waste plastic is converted into fuel, paper into handmade paper, uncooked vegetable waste is sent to be composted and used as manure in the permaculture farm, and cooked food waste is used in the generation of biogas. Metal scrap, for which there is no in-house conversion facility, is sold-off to scrap metal traders.

\subsubsection{Fuel Generation from Waste Plastic}

The pyrolysis plant, functional since 13 May 2015, uses the process of pyrolysis to convert waste plastic into industrial grade crude oil. Batches of $200 \mathrm{~kg}$ single-use plastic are converted over 8-9 hours into 100 liters of crude oil, with a residue of about $50 \mathrm{kgs}$ of carbon black, and fuel gas of $50 \mathrm{kgs}$. The crude oil is collected and subjected to distillation to yield pyrolysis oil, which is used not only to run the electrical generators at the Center but the plastic-to-fuel plant too. The fuel gas is used to heat the kitchen boilers. The carbon black goes sometimes in laying roads, or goes back to farmers for use in the fields.

\subsubsection{Handmade Paper Production}

Waste paper is mixed with waste cotton and converted into handmade paper. About $5 \mathrm{kgs}$ shredded paper waste is mixed with $2 \mathrm{kgs}$ of cotton waste, $100 \mathrm{gms}$ alum and $60 \mathrm{lts}$ of water and processed in the paper-making machine, generating 100-110 sheets of hand-made paper of A1 size. This is used to make stationery for several departments in the campus.

\subsubsection{Cooking Gas from Food Waste}

Food waste is converted into fuel in the 'Biourja' plant. Despite practices in place to reduce wastage, the kitchen is left with about 5 tons of cooked food waste per month, given the large number of meals served. 400-500 kgs of cooked food waste is processed every three days, producing $35-40 \mathrm{kgs}$ of biogas, and about $50 \mathrm{kgs}$ of bio-manure. The gas is used for the kitchen burners, while the manure goes back to the fields.

When the 1-ton plant is run to full capacity, 70-90 kgs of biogas and $100 \mathrm{kgs}$ of bio-manure is produced. 


\subsubsection{Compost from Green Waste}

All the uncooked food waste from the Center's kitchen and other plant waste from the campus is turned into compost at the permaculture farm, and contributes to regenerating the soil there.

\subsubsection{Biogas from Cow Dung}

The Center's unique gaushala, a dairy farm and cow shelter, houses hundreds of indigenous Indian cows. The cow dung and cow urine from this farm are used in natural farming to produce fertilizers as well as pesticides. Apart from being used as fertilizer for the Center's farms and in the conversion of food waste to fuel, cow dung is also used in the gobar gas generator to produce energy for the gaushala.

\subsubsection{Environmentally Friendly Briquettes}

Groundnut and coffee shells are converted into briquettes, and used as fuel for the Center's kitchen boilers as an occasional alternative to crude oil from the pyrolysis plant.

\subsubsection{Sewage Treatment}

The first Sewage Treatment Plant (STP) became operational in the year 2006. There are nine STPs in and around the Art of Living International Center at various locations. The Moving Bed Biofilm Reactor (MBBR), Solid Immobilized Bio-Filter (SIBF) system and Sequencing Batch Reactor (SBR) types of sewage treatment plants are functional here. Monthly testing includes analyzing Biological Oxygen Demand (BOD) and Chemical Oxygen Demand (COD) using a test-kit. When required, testing by a recognized private laboratory is also conducted to measure the color, odor, turbidity in NTU, $\mathrm{pH}$, chloride, COD, BOD (3 days at $27^{\circ}$ Celsius), oil and grease, sulphates, Total Dissolved Solids (TDS), Total Suspended Solids (TSS) and residual free chlorine.

The total treatment capacity of the STPs is 18 lakh liters per day. On average, 10 lakh liters of water is recycled every day, and the treated water is used in natural farming and gardening.

\subsection{Clean Energy}

\subsubsection{Solar Energy}

It has already been mentioned that various kinds of waste is converted into fuel at the Center. With respect to electricity, the Center has made an effort to reduce its dependence on electrical supply from the power grid, which is dependent on non-renewable resources. Solar power is generated through panels: with a total installed capacity of $347 \mathrm{kWp}$, about $40,000 \mathrm{kWh}$ of energy is generated, taking care of about $15 \%$ of the energy needs of the Center. Several of the residential blocks are powered by this energy, and solar water heaters are also used.

Work on installing panels with additional capacity $30 \mathrm{kWp}$ is almost complete. The Center has an ambitious plan to harness wind energy too in the future.

The high awareness about sustainable living has led to extending support to the International Solar Alliance as well: The Art of Living launched the International Interfaith Solar Alliance (IISA) during the World Culture Festival (WCF) in March 2016 to raise awareness about clean energy.

\section{Results}

\subsection{Natural Farming and Permaculture}

The kitchen at the Center feeds about 25,000 people per day during the lean season, and close to 30,000 people during the festive season. On some special occasions, such as the festivals of Shivaratri in March, or Navaratri in October-November, the number of people touches 1 lakh. Over 1.5 tons of vegetables and fruits are consumed daily during the lean season, and the consumption goes up to almost 2.5 tons during the peak season. These needs are met in-house to a large extent: through natural farming and permaculture, more than $150,000 \mathrm{kgs}$ of vegetables are produced at the Center on a monthly basis. It also clears the misconception that crop yields are low when grown using natural farming or permaculture.

The permaculture farm, which was described by the consultants as being "in a severely degraded state due to overgrazing, erosion and leaching of the soils" in 2013, is now a mini-forest with its own ecosystem. It is always busy with activity. Apart from farming, a one-day interactive course is conducted on a regular basis where informative and transformational facts are shared: not just about permaculture, but also about the Green and the White Revolutions, the importance of use of native Indian cows in agriculture, and a host of other important facts about life, earth, and life on earth.

\subsection{Waste Management}

The Center recycles almost 100 percent of its waste, including sewage. Plastic waste is converted into fuel, and 
the monthly production ranges between 1500-2000 liters. Tests show that the calorific value of this oil is equivalent to that of diesel. Cooked food waste is directed into the production of biogas and bio-manure, while plant waste is used to make compost as well as eco-friendly briquettes that are used as fuel. Paper and cloth waste are turned into handmade paper and stationery. Cow dung and urine produced in the gaushala is used as manure and as fuel, as well as being used to make natural fertilizers and pesticides. Domestic sewage is treated by means of different kinds of STPs and the treated water is used for plants.

\subsection{Clean Energy}

The use of solar power, while not being able to meet the demands of the Center in full, nevertheless reduces the load on the electricity grid.

\section{Discussion: Impact of Sustainable Initiatives in Reducing the Ecological Footprint}

The incorporation of sustainable living choices at the Art of Living International Center extends across all areas of life. The Center and its surroundings are part of a briskly urbanizing landscape. The administrative and residential structures, as well as the buildings that house various departments are spread over 65 acres (or 0.263 $\mathrm{km}^{2}$ ) of what was once barren, rocky land. Now, its green cover provides a home to numerous plant and animal species while meeting several of the needs of the Center. A good part of its vegetable and fruit needs - about 105 tons a month in lean times, and 165 tons in peak season - are met by the cultivation of another 400 acres of arable land in the surrounding area.

The community at the Center is well aware of the environmental degradation across the world due to the intensification of agricultural activities, and increased use of chemical pesticides and fertilizers. These anthropogenic activities not only pollute the soil and groundwater sources, but also affect ecosystem services such as natural pest control, pollination, nutrient cycling and the entire food chain. It has therefore adopted natural farming and permaculture as right agricultural practices, growing crops in accordance with nature.

The huge impact of permaculture as an aid to sustainable urbanization is also recognized. Pioneered by co-workers Bill Mollison and David Holmgren in the 1970s in Australia, permaculture is based on the recognition that local actions "have a far greater impact on the biosphere than originally intended" (Bambrey, 2014 [2006]). It therefore draws from allied fields like organic farming, integrated farming, and agroforestry to grow local and natural varieties of flora. Apart from making available chemical-free food, it prevents degradation by taking cognizance of soil (and topsoil) health and water-availability along with ecological problems and climate change. What makes it sustainable is that it operates in a 'closed system' where the waste output from one part of the system are used as inputs for other parts of the designed system.

The impact of such practices as natural farming and permaculture is clearly visible at the Center: over a period of 35 years, the once barren land has blossomed into a natural as well as a nurtured landscape where large numbers of species of both flora and fauna flourish.

Waste is a global issue, and it must be dealt with properly so that it does not pose a threat to public health and the environment. In India, the amount of solid waste, or Municipal Solid Waste (MSW), generated is high: in 2015 alone, urban India produced around $62 \mathrm{Mt}$ of MSW, comprised primarily of waste from households, offices, hotels, shopping complexes, institutions, and from municipal services such as street cleaning and maintenance of recreational areas. This amounts to $450 \mathrm{~g} / \mathrm{capita} / \mathrm{day}$, which is estimated to rise to $436 \mathrm{Mt}$ by 2050 (Sharma and Jain, 2019). Rapid urbanization, industrialization, exploding population and life-styles changes will cause this increase. Managing waste efficiently is thus essential, and it entails three types of activities: the collection, transportation, treatment and disposal of wastes, the controlling, monitoring and regulation of waste production, and the prevention of waste through modification, reuse and recycling (Dondapati et al., 2018).

Plastics, which now pervade everyday life from packing food to disposing garbage, form an integral part of MSW today. The use of polythene bags has seen an unprecedented increase over the past decade, and 5 trillion plastic bags were projected to be consumed in 2019 (The World Counts, 2019). The production of plastics increased nearly 200 -fold to 381 million tons in 2015 (Ritchie and Roser, 2018), but according to UNEP (2018), only nine per cent of the nine billion tons of plastic the world has ever produced has been recycled. The UNEP also states that by 2050 there will be about 12 billion tons of plastic litter in landfills and the natural environment.

Another large component of waste is food waste. A staggering 30 to 50 percent of the food produced annually for global human consumption goes waste. Industrial agriculture and corporatization of food have contributed to food waste both in the retail market as well as at the level of the consumer, not to mention food losses along the production and supply chains (Note 3). Food waste contributes much to greenhouse gas emissions.

The waste management practices at the Center account for both these types of waste. Using the technique of 
pyrolysis (Wong et. al., 2015; Miandad et. al., 2016; Kalargaris et. al., 2017), waste plastic is used to generate fuel at the Center, thereby reducing the plastic waste load on landfills. The Center successfully runs a pyrolysis plant. With regard to food, practices that have been put in place include the use of homegrown vegetables and food, cautioning people to only take what they can eat, and recycling of cooked food waste. While green food waste is composted, cooked food waste is used to not only produce fuel, but the residual substrate goes back to the soil.

Other than MSW, the other large source of waste is domestic sewage. At the Center, STPs are used to take effective care of such waste, and the treated water is efficiently reused.

Energy consumption has escalated globally due to urbanization and industrialization. Most of these energy demands are dependent on non-renewable sources that are limited in nature. Studies show that their exploitation not only affects their availability but also negatively impacts the climate. According to Owusu and AsumaduSarkodie (2016), the "return-to-renewables" on a large scale will help mitigate climate change as well as be sustainable for the present and future generations. Turning to renewable sources of energy like solar and wind is necessary. The Center, which is already using solar energy, is also now making an attempt to harness the power of the wind. Apart from this, converting waste into fuel also helps in reducing its dependence on non-renewable sources.

The Center could well be termed a 'mega permaculture site' - hardly anything goes waste here as the 'waste' products from one process becomes a resource or raw material for another. Through example, it contributes to the exploration of solutions to tackle the challenges associated with the degradation of environmental systems. A significant element here is people's participation: social engagement is the key element in creating sustainable communities, and at the Center, every individual and every visitor is a stakeholder and contributor to this effort. Raufirad et. al. (2017) report in their study on Isfahan, Central Iran, that they found that the three main sociocultural drivers of Sustainable Natural Resource Management (SNRM) were a sense of responsibility towards SNRM, participation with others in the conservation of natural resources and the use of people's knowledge in decisionmaking related to natural resources. Each of these aspects is also found in the people at the Center: it is evident from the fact that the Center is managed by volunteers that people's sense of responsibility as well as their participation is high. They also highlight the importance of sociocultural and religious beliefs as drivers of Local People's Participation (LPP), as they can motivate local people to voluntarily engage in SNRM both as individuals and as a part of larger, organized programs. At the Center, the plethora of sustainable initiatives that exist attests to the extensive use of the knowledge of numerous people. At the same time, unlike in the case of Isfahan, this 'peoples' movement' is undergird not by religious belief but by the practice of breathing techniques like the Sudarshan Kriya Yoga (SKY ${ }^{\mathrm{TM}}$ ) and associated meditation techniques. SKY and other meditation techniques, which are a part of the Center's programs, are practiced by the people associated with the Center regularly. A study by Rau et al. (2018) corroborates that such techniques, apart from bringing about a profound change in people's health and attitudes, also significantly enhances their sense of connectedness with and sensitivity to nature, and thus their concern for, and engagement with, their environment and with nature as a whole. Social engagement with environment sustainability efforts and action becomes an unforced response, and they are motivated both individually and as a community to work towards to the achievement of sustainability goals.

\section{Conclusion}

Bringing sustainability in all our lifestyle choices is the need of the hour, which will go a long way in contributing to our fight against global warming and climate change. The sustainable practices adopted at the Art of Living International Center set an example worth emulating. This can be attributed to the shift in mind-set of the local community from 'use and dispose' to 'reduce, reuse and recycle'. When every aspect of human life including food consumption and developmental activities are aligned in accordance with nature/the environment, the resulting ecological footprint would naturally be lower. It represents meeting everyone's need in the present without compromising the needs of future generations.

\section{Acknowledgements}

The authors are thankful to the Ashram Administration and the various Departments at The Art of Living International Center, Bengaluru, as well as to Sunitha K. Rao and Sheel Parekh for the help and assistance rendered during this research.

\section{References}

Art of Living permaculture site, The. Internal document of the Art of Living. N.p. 15 July 2013.

Bambrey, R. J. (2014). Permaculture - what's that? Country Smallholding. Retrieved from https://www.countrysmallholding.com/how-to-s/lifestyle/permaculture-what-s-that-1-3493435 
Bibri, S. E., \& Krogstie, J. (2017). Smart sustainable cities of the future: An extensive interdisciplinary literature review. Sustainable Cities and Society, 31, 183-212. https://doi.org/10.1016/j.scs.2017.02.016

Built up area of Bangalore in India from 1975 to 2015. Retrieved from https://www.statista.com/statistics/911313/india-built-up-area-bangalore

Dondapati, S. K. S., Ravikumar, T. S., Gutji, V. R., Ade, A. D., Deekala, R. S., \& Kondagunta, N. (2018). A comparative study of general waste management practices in a campus of a medical university located in the purview of a municipal corporation of a South Indian state. International Journal of Community Medicine and Public Health, 5, 5115-5120. https://doi.org/10.18203/2394-6040.ijcmph20184721

FAO. (2011). Women in Agriculture: Closing the gender gap for development. The State of Food and Agriculture 2010-2011 (pp. 1-62). Retrieved from http://www.fao.org/3/i2050e/i2050e00.htm

Geographic location of Bengaluru. Retrieved from https://worldmapwithcountries.net/2020/03/12/india-mapwith-states/

Holmgren, D. (2002). Permaculture: Principles and Pathways Beyond Sustainability. Denmark: Holmgren Design Services.

IQAir. 2019 World Air Quality Report: Region \& city PM2.5 ranking. 2020 Report V8 (2020). Retrieved from https://www.iqair.com/world-most-polluted-cities. Acc. 11 June 2020.

Kalargaris, I., Tian, G. and Gu, S. (2017). Combustion performance and emission analysis of a DI engine using plastic pyrolysis oil. Fuel Processing Technology, 15, 108-115. https://doi.org/10.1016/j.fuproc.2016.11.016

Location of The Art of Living International Center in relation to the city of Bengaluru. Google Maps. Retrieved from https://goo.gl/maps/adFa8r3yHyjvBX38

Miandad, R., Barakat, M. A., Aburiazaiza, A. S., Rehan, M., \& Nizami, A. S. (2016). Catalytic pyrolysis of plastic waste: A review. Process Safety and Environmental Protection, 102, 822-838. https://doi.org/10.1016/j.psep.2016.06.022

Mollison, B., \& Holmgren, D. (1979). Permaculture one: A perennial agriculture for human settlements. Australia: Transworld Publishers.

Owusu, P. A., \& Asumadu-Sarkodie, S. (2016). A review of renewable energy sources, sustainability issues and climate change mitigation. Cogent Engineering, 3, 1167990. https://www.tandfonline.com/doi/full/10.1080/23311916.2016.1167990

Rau, N., Ingole, S., Air Commodore Kulkarni, S. VSM (retd.), \& Kanchibhotla, D. (2018). Effect of Sudarshan Kriya YogaTM and associated meditation techniques on the connection and sensitivity towards environment. International Journal of Innovative Research in Science, Engineering and Technology, 7(12), 11899-11909.

Raufirad, V., Hunter, R., Khalili, R., \& Bagheri, S. (2017). Drivers of local people's participation in sustainable natural resource management: a case study in central Iran. The International Journal of Justice and Sustainability, 22, 880-893. https://doi.org/10.1080/13549839.2017.1297391

Ritchie, H., \& Roser, M. (2018). Plastic pollution. OurWorldInData.org. Retrieved from https://ourworldindata.org/plastic-pollution.

Sharma, K. D., \& Jain, S. (2019). Overview of municipal solid waste generation, composition, and management in India. Journal of Environmental Engineering, 145(3). https://doi.org/10.1061/(ASCE)EE.19437870.0001490

Soma, T. (2018). (Re)framing the food waste narrative: infrastructures of urban food consumption and waste management in Indonesia. Indonesia, 105, 173-190. https://doi.org/10.1353/ind.2018.0007

The Art of Living. Retrieved from https:/www.artofliving.org/in-en/projects/environmental-sustainability/7reasons-why-the-art-of-living-international-center-is-a-truly-sustainable-campus

The World Counts. (2019). Retrieved from https://www.theworldcounts.com

UN Habitat. (2012). United Nations System Task Team on the Post-2015 UN Development Agenda. Sustainable urbanization: Thematic think piece. Retrieved from https://www.un.org/millenniumgoals/pdf/Think\%20Pieces/18_urbanization.pdf

United Nations Department of Economic and Social Affairs [UNDESA]. (2019). World urbanization prospects: The 2018 revision. Retrieved from https://population.un.org/wup/Publications/Files/WUP2018-Report.pdf 
United Nations Environment Programme [UNEP]. (2018). Single-use plastics: A roadmap for sustainability. Retrieved from https://www.unenvironment.org/resources/report/single-use-plastics-roadmap-sustainability

Wilson, D., Rodic, L., Modak, P., Soos, R., Carpintero Rogero, A., Velis, C., Iyer, M., \& Simonett, O. (2015). Global Waste Management Outlook. UNEP and International Solid Waste Association [ISWA]. Retrieved from https://www.researchgate.net/publication/283085861

Wong, S. L., Ngadi, N., Abdullah, T. A. T., \& Inuwa, I. M. (2015). Current state and future prospects of plastic waste as source of fuel: A review. Renewable and Sustainable Energy (Reviews), 50, 1167-1180. https://doi.org/10.1016/j.rser.2015.04.063

World Population Review. (2017). Retrieved from www.worldpopulationreview.com

\section{Notes}

Note 1. According to https://www.statista.com/statistics/911313/india-built-up-area-bangalore/, $421.76 \mathrm{~km} 2$ of its $741 \mathrm{~km} 2$ (approximately 57\%) was built up as of 2015 .

Note 2. This description is taken from an internal document, The Art of Living permaculture site, shared by The Art of Living International Center.

Note 3. Soma draws these figures from Food and Agriculture Organization (FAO), "Global Food Losses and Food Waste" (Study conducted for the International Congress "Save Food at Interpack," May 12-18, 2011, Düsseldorf, Germany); and British Institute of Mechanical Engineers (IMG), "Global Food: Waste Not, Want Not," November 2, 2013, http://www.imeche.org/knowledge/themes/environment/global-food.

\section{Copyrights}

Copyright for this article is retained by the author(s), with first publication rights granted to the journal.

This is an open-access article distributed under the terms and conditions of the Creative Commons Attribution license (http://creativecommons.org/licenses/by/4.0/). 